\title{
Impact of the photosensitizers hematoporphyrin coated gold nanoparticles on biomphalaria alexandrina snails
}

\author{
Karem El-Hommossany ${ }^{1}$, S. A. El-Sherbibni ${ }^{2}$ \\ ${ }^{1}$ Medical Malacology Department, Theodor Bilharz Research Institute, Giza, Egypt; \\ ${ }^{2}$ National Institute of Laser Enhanced Scince, Giza, Egypt; Karmelhommossany@yahoo.com
}

Received 27 April 2011, revised 11 May 2011, accepted 27 June 2011.

\begin{abstract}
The present study was done using two concentrations of the photosensitizer Hematoporphyrin coated Gold Nanoparticles $\left(\mathrm{HpdGNP}_{3}\right)\left(5 \times 10^{-6}\right.$, $5 \times 10^{-5}$ mole/dicemeter $^{-3}$ ), to evaluate their efficacy on survival rate, egg-laying capacity of Biomphalaria alexandrina snails and on histological deteriorations in their hermaphrodite gland. B. alexandrina snails were incubated for 12 hours at each tested concentration in the dark, thereafter they were exposed to direct sunlight $\left(336.2 \mathrm{~W} / \mathrm{m}^{2}\right)$ for either 2 or 4 hours followed by 24 hours of recovery. Control snails were treated with these concentrations without exposure to light irradiance. Another experiment was carried out simultaneously and the snails were left for 4 weeks of recovery to evaluate their egg-laying capacity (Mx). The results indicate that $5 \times 10^{-5} \mathrm{Mdm}^{-3}$ (HpdGNPs) with 4 hours of exposure sunlight suppressed the survival rate of $B$. alexandrina snails by $50 \%$. Meanwhile, control snails incubated with $5 \times$ $10^{-5} \mathrm{Mdm}^{-3} \mathrm{HpdGNPs}$ were not affected and still alive $(100 \%)$. For snail's fecundity $(\mathrm{Mx})$, treated snails laid low number of eggs throughout the recovery period (4 weeks), in comparison with that of control ones. The highest value of $M x$ for snails treated with $5 \times 10^{-5} \mathrm{Mdm}^{-3} \mathrm{Hpd}$ coated GNPs was recorded at the $3^{\text {rd }}$ week of recovery period, being 6.7 eggs/snail, compared to 37.6 eggs/control snail. This has a negative reflect on the reproductive rate $\left(R_{\mathrm{o}}\right)$ of treated snails as it was reduced under these conditions by $76.6 \%$ and $86.1 \%$, respectively.Histological tests revealed injuries in spermatocytes, oocytes, several degenerations of B.alexandrina hermaphrodite gland then evacuations in many gonad's cells which severely suppressed their capacity for egg-laying. It is concluded from the present
\end{abstract}

work that exposing B. alexandrina snails to sublethal concentrations of the photosensiter Hpd coated GNPs (12 hours incubation, 4 hours exposure to $336.2 \mathrm{~W} / \mathrm{m}^{2}$ ) significantly reduced their reproductive capacity that may have a negative reflect on schistosomiasis transmission.

Keywords: Biomphalaria Alexandrina Snails; Hematoporphyrin Coated Gold Nanoparticles; Snail's Egg-Laying Capacity; Histology

\section{INTRODUCTION}

Schistosomiasis is an important public health prblem in Egypt and several developing countries (Pasvol and Hoffman, 2001). Control of this parasitic disease could be through treatment of infected persons, health education, sanitation and snail control. Thus, snail control strategies are considered a priority for preventing or minimizing schistosomiasis transmission (Lardans and Dissous, 1998). These strategies have been based upon elimination of the snail intermediate hosts chemically, biologically or environmentaly. However, further techniques are required in this field. So, phtosensitizing compounds could be evaluating for controlling noxious water parasites, since sunlight activated dyes characterized by a high efficiency, lack of mutagenic activity and negligible toxicological risk to humans and other mammalian species (Ben Amor et al, 1998).

Hematoporphyrin derivatives have been used as phtosensitizing agent in the presence of sunlight as well as artificial light (Spikes, 1984). Later, Abdel-Kader et al (2001) observed that incubation of Lymnaea natalensis snails with $10^{-3} \mathrm{Mdm}^{-3}$ Hematoporphyrin (Hpd) for 12 hrs, followed by $30 \mathrm{~min}$ of exposure to sunlight (300 $\mathrm{W} / \mathrm{m}^{2}$ ) killed these snails after 24 hrs of recovery. El-Tarky (2005) noticed that mortality rate of adult $B$. alexandrina snails exposed for $4 \mathrm{hrs}$ to $438.8 \mathrm{w} / \mathrm{m}^{2}$ of sunlight after 12 hours of their incubation with $10^{-5}$ 
Hpds, was 52\%. The author added that the effect of Hpds against snails increased in the alkaline media $(\mathrm{pH}$ $=8)$, while it decreased at the acidic ones $(\mathrm{pH}=6)$. It was stated that porphyrins and their derivatives exhibited a potent phytotoxic effect against gram-positive bacteria (Bertoloni et al., 1993). In 2006, El-Sayed and El-Sherbini recorded that $\mathrm{LC}_{50}$ of Hematoporphyrin (Hpd) against adult B. alexandrina snails was $5 \times 10^{-5}$ $\mathrm{M} / \mathrm{dm}^{-3}$ after 12 hours of incubation and 2 hours of irradiation at $\sim 336 \mathrm{~W} / \mathrm{m}^{2}$ in sunlight and at $2 \times 10^{-5} \mathrm{Mdm}^{-3}$ Hpd, they did not lay eggs. The authors added that infection rates of these snails with $S$. mansoni were significantly suppressed by their exposure to $2 \times 10^{-5} \mathrm{Mdm}^{-3}$ Hematoporphyrin (Hpd) either pre- or postmiracidial exposure, in addition to the significant reduction in cercarial production/snails treated with $4 \times 10^{-5} \mathrm{Mdm}^{-3} \mathrm{Hpd}$. Moreover, histological examinations showed a sever damage in the hermaphrodite gland of snails exposed to the sublethal concentrations of Hpd.

Recentely, Ragheb (2009) stated that incubation of $B$. truncatus snails for $24 \mathrm{hrs}$ at $10^{-4} \mathrm{M} / \mathrm{L}$ gold nanoparticls (GNPs) in dark followed by 2 hours of exposure to 650 $\mathrm{W} / \mathrm{m}^{2}$ irradiance (Solar Simulator) resulted in $100 \%$ death of snails. The author added that decreasing GNPs concentration to $10^{-5} \mathrm{M} / \mathrm{L}$ significantly reduced the snail's reproductive rate $\left(\mathrm{R}_{0}\right)$ by $48.3 \%$ compared to that of control, and this was partially due to the recorded damage in hermaphrodite gland cells of treated snails. Therefore, the present study aims to evaluate the efficacy of Hematoporphyrin coated Gold Nanoparticles on survival rate, egg-laying capacity of $B$. alexandrina snails and on their hermaphrodite gland cells histologically.

\section{MATERIALS AND METHODS}

\subsection{Snails}

Biomphalaria alexandrina snails (6 - $9 \mathrm{~mm}$ ) were laboratory produced in Medical Malacology Department at Theodor Bilharz Research Institute (TBRI), Giza, Egypt.

\subsection{Hematoporphyrin Coated Gold Nanoparticles}

A stock Mole/decimeter 3 Hpds concentration Mole/ decimeter 3 was prepared by dissolving $672 \mathrm{mg}$ of Hpds in $100 \mathrm{ml}$ of glycerol by stirring overnight and kept in dark. In $250 \mathrm{ml}$ conical flask $5 \mathrm{ml}$ of the stock solution was added to $100 \mathrm{ml}$ of glycerol and boiled with stirring. To the solution $0.01699 \mathrm{~g} \mathrm{HAuCl} 4$ was added and the mixture continue boiling until the color of the mixture changes from red to win red. Heating was removed and stirring continued till cooling to room temperature. The final cocentration is $5 \times 10^{-4} \mathrm{Mdm}^{-3}(\mathrm{Hpd}+\mathrm{Au})$.

\subsection{Molluscicidal Activity of Hematoporphyrin Coated Gold Nanoparticles}

Two concentrations of Hematoporphyrin coated Gold Nanoparticles $\left(5 \times 10^{-6}, 5 \times 10^{-5} \mathrm{Mdm}^{-3}\right.$ ) were prepared according to El-Tarky (2005) and Ragheb (2009) results, as $10-4 \mathrm{Mol} / \mathrm{dm}^{-3}$ from each of Hpd and GNPs was lethal to B. alexandrina and B. truncatus snails, respectively. Therefore, B. alexandrina (6 - $8 \mathrm{~mm})$ were incubated for 12 hours at each tested concentration in the dark, thereafter they were exposed to light irradiance $\left(336.2 \mathrm{~W} / \mathrm{m}^{2}\right)$ for either 2 or 4 hours. Three replicates for each light exposure period, each of 10 snails $/ 500 \mathrm{ml}$, were prepared. After that, snails were washed thoroughly with dechlorinated water and maintained in clean water for 24 hours of recovery then mortality rates were recorded. Control snails were treated simultaneously as the tested ones, without exposure to light irradiance. Death of snails was determined by changes in appearance of the shell and internal body (Nolan et al., 1953).

\subsection{Effect of Hematoporphyrine Coated Gold Nanoparticles on Snail's Egg-Laying Capacity}

B. alexandrina snails (7 - $9 \mathrm{~mm}$ ) were incubated once for 12 hours in the dark with sublethal concentrations (5 $\times 10^{-5}$ and $5 \times 10^{-6} \mathrm{Mdm}^{3}$ ) of Hematoporphyrin coated gold nanoparticles, after that they were exposed to direct sunlight of $336.2 \mathrm{~W} / \mathrm{m}^{2}$ for 4 hours. Then, they were transferred to clean dechlorinated water and maintained under laboratory conditions $\left(25^{\circ} \mathrm{C}\right)$ for 4 weeks. Two replicates, each of 15 snails/L dechlorinated water, were used for each concentration and control group. Each aquarium was provided with polythylene sheets for oviposition. The snails were daily fed oven dried lttuce leaves, dead ones were removed and the survival rate were recorded weekly. The survivorship (Lx) and number of eggs/snails (Mx) were recorded weekly (Southwood, 1978).

\subsection{Histology}

Histological preparations were done for snails incubated for 12 hours to the two concentrations, $5 \times 10^{-6}$ and $5 \times 10^{-5} \mathrm{Mdm}^{-3}$, followed by 2 and 4 hours exposure to direct sunlight $\left(336.2 \mathrm{~W} / \mathrm{m}^{2}\right)$. Control snails were treated with these concentrations without exposure to light irradiance. The hermaphrodite gland of treated and control snail groups was carefully incised using fine 
scissors and dropped into a fixative Bouin's solution, then the sections (5 - $8 \mu \mathrm{m})$ were stained with delafield's haematoxylin and eosin according to Mohamed and Saad (1990).

\subsection{Statistical Analysis}

Survival rates of treated snails were analyzed by Chi-square values of contingency tables (Southwood, 1978).

\section{RESULTS}

From Table 1, it is clear that $5 \times 10^{-5} \mathrm{Mdm}^{-3}$ (HpdGNPs) with 4 hours of exposure to $336.2 \mathrm{w} / \mathrm{m}^{2}$ sunlight suppressed the survival rate of $B$. alexandrina snails by $50 \%$. Meanwhile, control snails incubated with $5 \times 10^{-5} \mathrm{Mdm}^{-3}$ HpdGNPs were not affected and still alive (100\%). It is also, seen that snail's survival rate was concentration and light period dependent. So, increasing the concentration from $5 \times 10^{-6}$ to $5 \times 10^{-5}$ $\mathrm{Mdm}^{-3}$ reduced the survival rate from $100 \%$ to $62.7 \%$, respectively. Similar conclusion was observed by elongation of the light exposure period from 2 to 4 hours, as the rates of snails incubated with $5 \times 10^{-5} \mathrm{Mdm}^{-3}$ decreased from $62.7 \%$ to $50 \%$, respectively.

The data in Table 2 and (Figure 1 and 2) represent the effect of $5 \times 10^{-6}$ and $5 \times 10^{-5} \mathrm{Mdm}^{-3} \mathrm{Hpd}$ coated GNPs on snail's fecundity $(\mathrm{Mx})$ and their survivorship (Lx) post 4 weeks of recovery followed their exposure once to this compound. It was observed that survivorship (Lx) of treated snails was significantly decreased during the $1^{\text {st }}, 2^{\text {nd }}$ and $3^{\text {rd }}$ weeks of recovery in comparison with that of control group $(P<0.01)$. The $\mathrm{Lx}$ values of snails exposed to $5 \times 10^{-6}$ and $5 \times 10^{-5} \mathrm{Mdm}^{-3} \mathrm{Hpd}$ coated GNPs at the $1^{\text {st }}$ week were 0.75 and 0.46 , respectively compared to 1.00 for control ones. It was also, noticed that survived snails at $5 \times 10^{-5} \mathrm{Mdm}^{-3} \mathrm{Hpd}$ coated GNPs tried to somewhat overcome the harmful effects of the tested compound through the $2^{\text {nd }}$ and $3^{\text {rd }}$ weeks of recovery as their Lx was stable, being 0.46 , but they suffered from another significant reduction in this parameter at the $4^{\text {th }}$ week $(\mathrm{Lx}=0.23)$ compared to 0.6 for control ones $(P<0.05)$.

Table 1. Survival rate (\%) of Biomphalaria alexandrina snails exposed to Hematoporphyrin coated gold nanoparticles (12 hours incubation, and 4 hours exposure to $336.2 \mathrm{~W} / \mathrm{m}^{2}, 24$ hours recovery).

\begin{tabular}{ccc}
\hline Concentrationm & $\begin{array}{c}\text { Survival rate (\%) } \\
\text { after }\end{array}$ & $\begin{array}{c}\text { Light exposur } \\
\text { for }\end{array}$ \\
\hline $\left.\mathbf{( M d m}^{-3}\right)$ & 2 hours & 4 hours \\
$5 \times 10^{-6}$ & 100 & 66.7 \\
$5 \times 10^{-5}$ & 62.7 & 50.0 \\
Control $^{*}$ & 100 & 100 \\
\hline
\end{tabular}

*Incubated with $5 \times 10^{-5} \mathrm{Mdm}^{-3}$ without light exposure.
For snail's fecundity (Mx), treated snails laid low number of eggs throughout the recovery period (4 weeks), in comparison with that of control ones. The highest value of $\mathrm{Mx}$ for snails treated with $5 \times 10^{-5}$ $\mathrm{Mdm}^{-3}$ Hpd coated GNPs was recorded at the $3^{\text {rd }}$ week of recovery period, being 6.7 eggs/snail, compared to 37.6 eggs/control snail. This has a negative reflect on the reproductive rate $\left(R_{0}\right)$ of treated snails as it was 20.3 and 11.8 for groups exposed to $5 \times 10^{-6}$ an $5 \times 10^{-5} \mathrm{Mdm}^{-3}$ of this compound, respectively, compared to 84.8 for control group. The reduction rates of this parameter in this case were $76.1 \%$ and $86.1 \%$, respectively.

Histological effects on the hermaphrodite gland of $B$. alexandrina snails revealed that the hermaphrodite gland of control snails (Plate 1) consists of a number of closely connected tubules where each tubule is lined with distinct germinal epithelium gives rise to all the stages of oogenesis and spermatogenesis. Oogonia are found in groups which are arranged along the periphery of the tubules. Oocytes are usually aggregated in the lumen of the tubules. The mature ova deeply stained with $\mathrm{H}-\mathrm{E}$ than oocytes due to the accumulation of yolk material in their cytoplasm. On the other hand, spermatogonia become arranged in small groups along the side walls of the tubules. As a result of their division, spermatocytes are produced. Spermatids are developed from the secondary spermatocytes and are found in small groups around them. Spermatozoa (sperms) are found in large groups free in the lumen; each consists of an oval head and thread like long tail (Mohamed and Saad, 1990).

For snails treated with Hpd coated GNPs $\left(5 \times 10^{-6}\right.$ and $5 \times 10^{-5} \mathrm{Mdm}^{-3}$ ), Plates 2 and 3 indicated that the cells of their hermaphrodite gland suffered from injuries in spermatocytes, oocytes, besides several degenerations then evacuations were seen in many gonad's cells. The acini lost their normal shape and an almost damage to their connective tissues was noticed which severely suppressed their capacity for egg-laying.

\section{DISCUSSION}

The present lethal effect of the photosensitizer Hematoporphyrin coated gold Nanoparticles (Hpd coated GNPs) against B. alexandrina snails was in parallel with that of Hpd on L. natalensis (Abd El-Kader et al., 2001) and B. alexandrina snails (El-Tarky, 2005 and El-Sayed and El-Sherbini, 2006). As well, the harmful effects of GNPs against B. truncatus snails (Ragheb, 2009) support the present study.

Concerning snail's fecundity $(\mathrm{Mx})$ and reproductive rate (Ro), the present results showed that exposure of B. alexandrina snails to Hpd coated GNPs markedly reduced these parameters. This could be attributed to the 
Table 2. Survivorship $\left(\mathrm{L}_{\mathrm{x}}\right)$ and fecundity $\left(\mathrm{M}_{\mathrm{x}}\right)$ of Biomphalaria alexandrina snails exposed to Hematoporphyrin coated gold nanoparticles (12 hours incubation, 4 hours exposure to $336.2 \mathrm{~W} / \mathrm{m}^{2}$ sunlight).

\begin{tabular}{|c|c|c|c|c|c|c|c|c|c|}
\hline \multirow{2}{*}{$\begin{array}{c}\text { Observation } \\
\text { Period (week) }\end{array}$} & \multicolumn{3}{|c|}{ Control } & \multicolumn{3}{|c|}{$5 \times 10^{-6} \mathrm{Mdm}^{-3}$} & \multicolumn{3}{|c|}{$5 \times 10^{-5} \mathrm{Mdm}^{-3}$} \\
\hline & $\mathrm{L}_{\mathrm{x}}$ & $\mathrm{M}_{\mathrm{x}}$ & $\mathrm{L}_{x} \mathrm{M}_{\mathrm{x}}$ & $\mathrm{L}_{\mathrm{x}}$ & $M_{x}$ & $\mathrm{~L}_{x} \mathrm{M}_{\mathrm{x}}$ & $\mathrm{L}_{\mathrm{x}}$ & $\mathrm{M}_{\mathrm{x}}$ & $\mathrm{L}_{\mathrm{x}} \mathrm{M}_{\mathrm{x}}$ \\
\hline 0 & 1.00 & 6.7 & 6.7 & 1.00 & 6.7 & 6.7 & 1.00 & 6.7 & 6.7 \\
\hline 1 & 1.00 & 14.0 & 14.0 & $0.75^{* * *}$ & 3.7 & 2.8 & $0.46^{* * *}$ & 2.2 & 1.0 \\
\hline 2 & 1.00 & 5.6 & 5.6 & $0.75^{* * *}$ & 1.2 & 0.9 & $0.46^{* * *}$ & 0.8 & 0.4 \\
\hline 3 & 1.00 & 37.6 & 37.6 & $0.50^{* * *}$ & 8.2 & 4.1 & $0.46^{* * *}$ & 6.7 & 3.1 \\
\hline 4 & 0.60 & 34.9 & 20.9 & 0.33 n.s. & 17.7 & 5.8 & $0.23^{*}$ & 2.6 & 0.6 \\
\hline $\mathbf{R}_{0}=$ & & & 84.8 & & & 20.3 & & & 11.8 \\
\hline
\end{tabular}

$\mathrm{L}_{\mathrm{x}}=$ Survivorship, $\mathrm{M}_{\mathrm{x}}=$ Mean number of eggs/snail/week; $\mathrm{R}_{\mathrm{o}}=$ net reproductive rate, Sum $\mathrm{L}_{\mathrm{x}} \mathrm{M}_{\mathrm{x}} ;{ }^{* * * *}=$ Highly Significant, $P<0.01 ;{ }^{*}=$ Significant, $P<0.05$; n.s. $=$ Not significant, $P>0.05$.

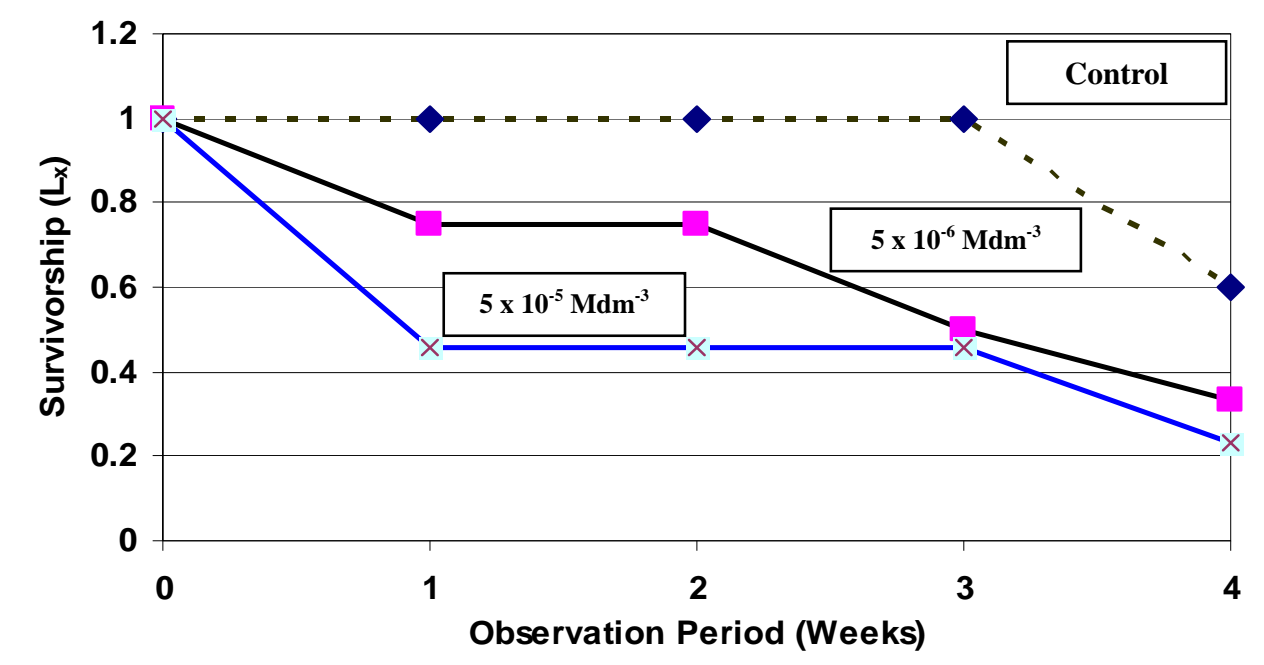

Figure 1. Survivorship (Lx) of Biomphalaria alexandrina snails exposed to Hematoporphyrin coated gold nanoparticles (12 hrs incubation and 4 hrs exposure to $336.2 \mathrm{~W} / \mathrm{m}^{2}$ sunlight).

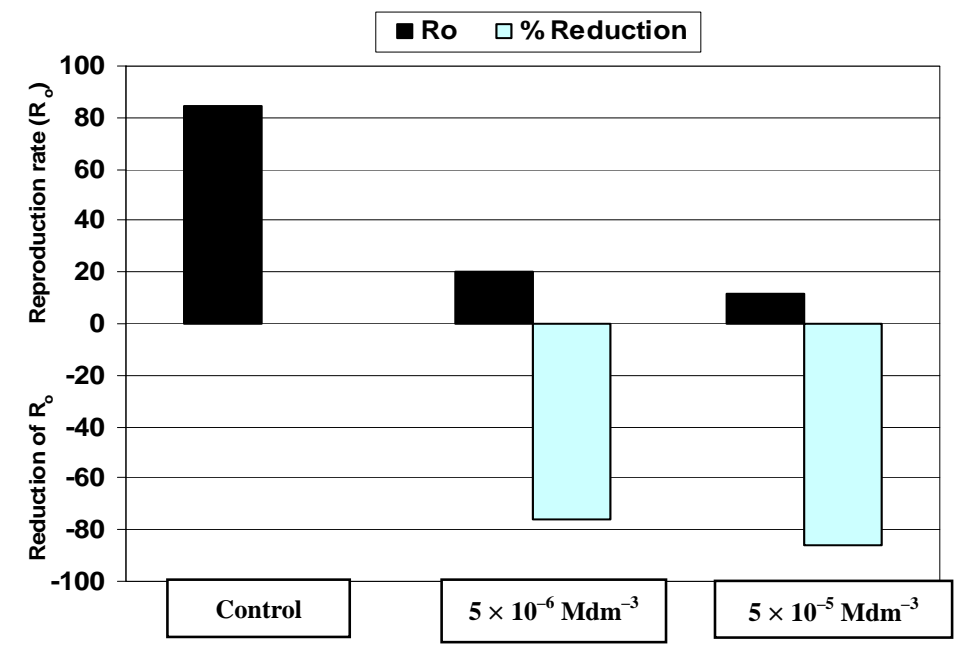

Figure 2. Reproduction rate $\left(\mathrm{R}_{0}\right)$ of Biomphalaria alexandrina exposed to Hematoporphyrin coated gold nanoparticles (12 hrs incubation and 4 hrs exposure to $336.2 \mathrm{~W} / \mathrm{m}^{2}$ sunlight). 


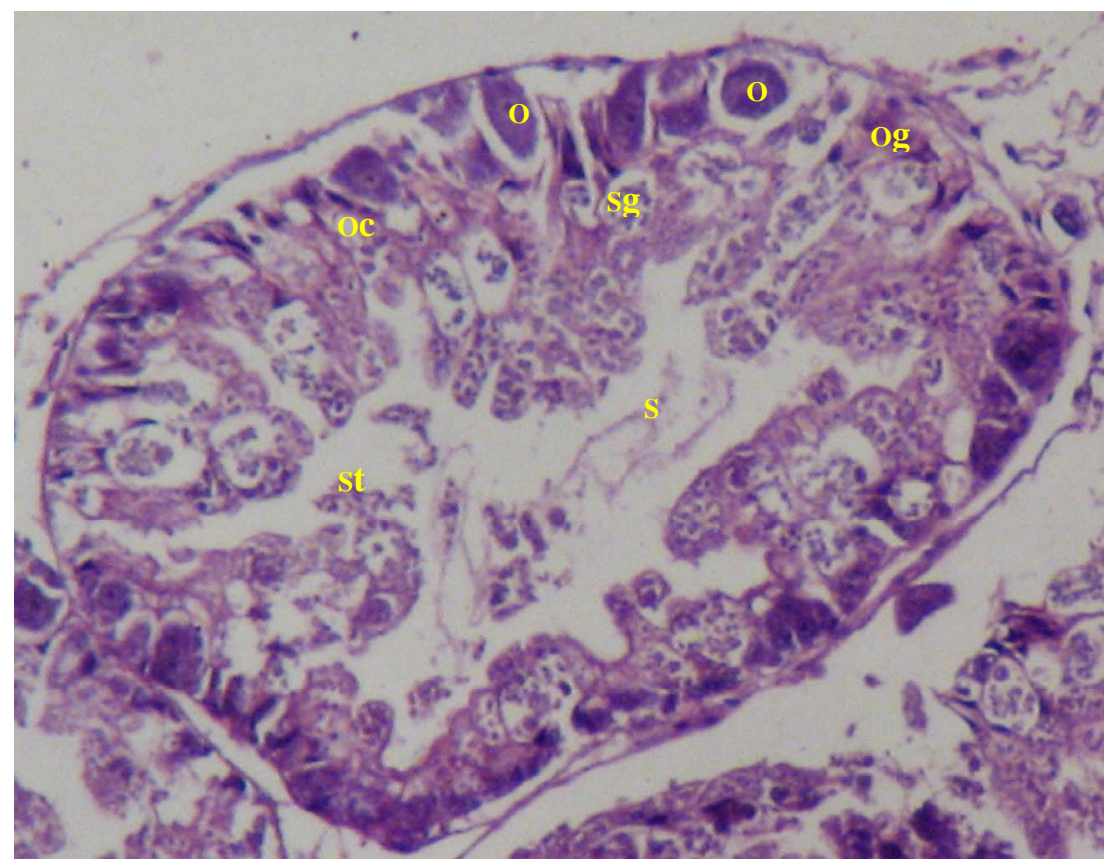

Plate 1. Light photomicrograph transverse section in the hermaphrodite gland of unexposed Biomphalaria alexandrina snails (Control), x 500. $\mathrm{O}=\mathrm{ova}$; $\mathrm{Og}=$ Oogonia; Oc= oocyte; $\mathrm{Sg}=$ Spermatogonia; $\mathrm{St}=$ Spermatid; $\mathrm{S}=$ sperms.

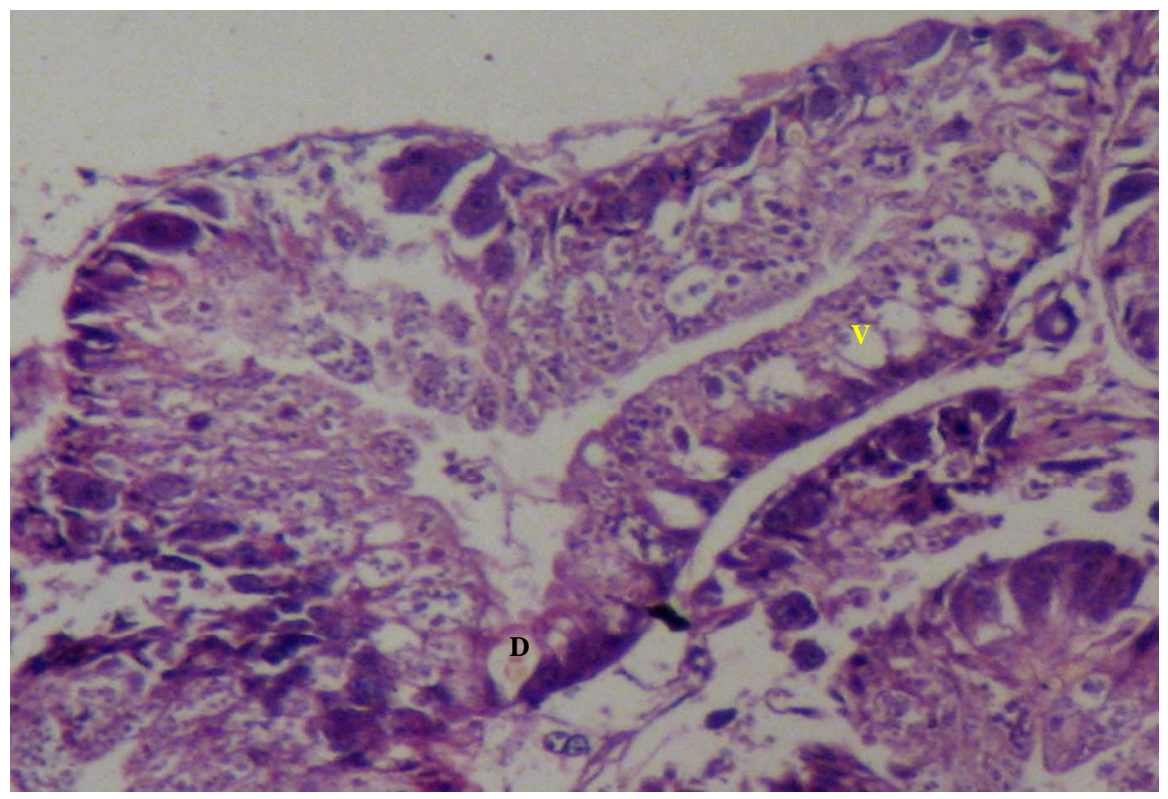

Plate 2. Light photomicrograph transverse section in the Hermaphrodite gland of B. alexandrina snails treated with 5x10-6 Mdm-3 Hematoporphyrin coated Gold nanoparticles, exposed to direct sunlight for $4 \mathrm{hrs}, \mathrm{x} 500 \mathrm{D}$ = Degenerated cells; V = Vacuoles.

harmful effects of this compound on physiological ac-tivities and reproductive system of treated snails, hence considerably reduced their oviposition. This was supported by the present histological results (Plates 2 and 3) on the hermaphrodite gland of snails exposed to this compound. These plates revealed marked damages to the gland cells in addition to several evacuations of its tu-

Copyright $(2011$ SciRes. bules from gametogenic stages. This should greatly re duce the offspring of survived snails, hence has a negative reflect on schistosomiaisis transmission. These observations are in accordance with the previous ones on Hpd against oviposition of B. alexandrina snails (ElSayed and El-Sherbini, 2006) and on GNPs against reproductive rate of B. truncatus snails (Ragheb, 2009).

Openly accessible at http://www.scirp.org/journal/OJAS/ 


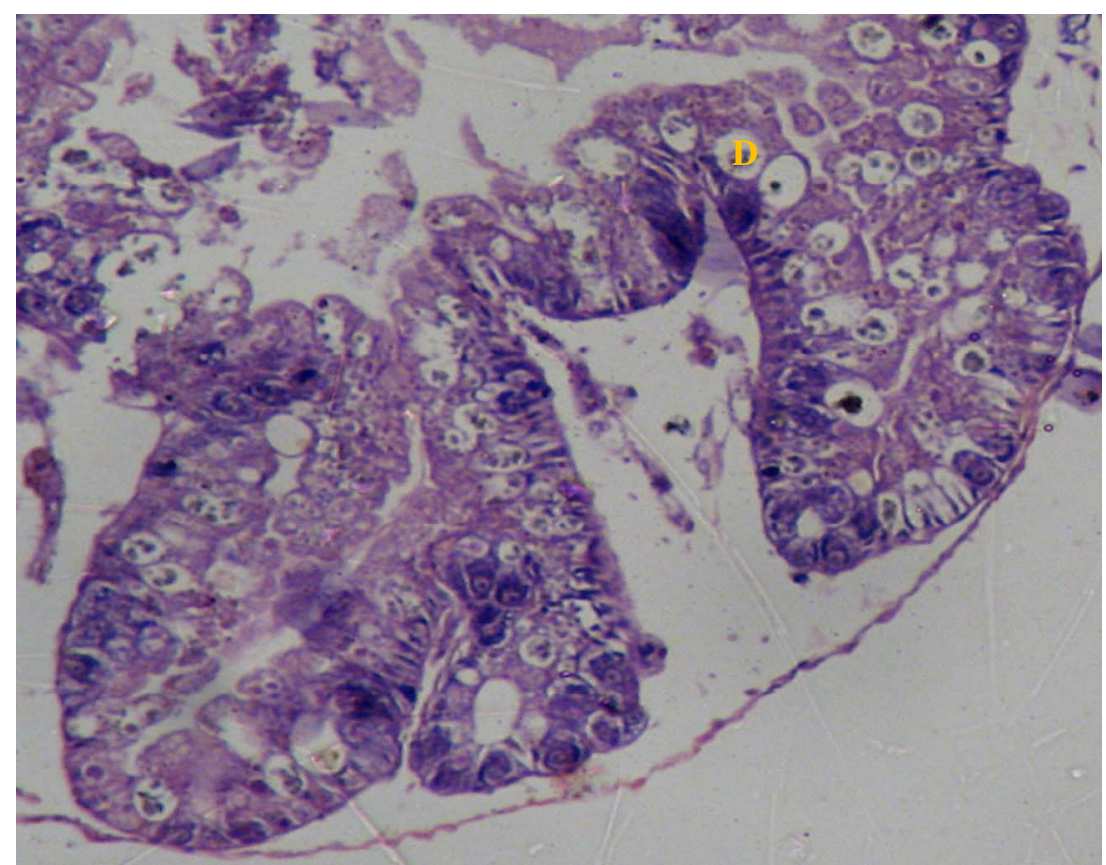

Plate 3. Light photomicrograph transverse section in the hermaphrodite gland of $B$.alexandrina snails treated with $5 \times 10^{-5} \mathrm{Mdm}^{-3}$ Hematoporphyrin coated Gold nanoparticles, exposed to direct sunlight for 4hrs, $\mathrm{x}$ 500.D = Degenerated cells.

The harmful effects of Hpds could be partially due to their hydrophobic character, hence localization in and damage the cellular membrane leading to cells death (Ben Amor et al, 1998). As well, these photosensitizers damage the biological targets by photosensitized oxidation which deactivate certain enzymes through destruction of specific amino acids (e.g. Methionine and tryptophan), nucleic acid (Primarily of guanine) and by oxidation of unsaturated fatty acids and cholesterol in cell membrane (Abd El-Meguid, 1996). In addition, precipitated GNPs inside snail's tissues when irradiated with some forms of light energy they absorb light and emit localized heat with its lethal or traumal effects (Jana et al, 2007).

It is concluded from the present work that exposing B. alexandrina snails to sublethal concentrations of the photosensiter Hpd coated GNPs (12 hours incubation, 4 hours exposure to $336.2 \mathrm{~W} / \mathrm{m}^{2}$ ) significantly reduced their reproductive capacity that may have a negative reflect on schistosomiaisis transmission.

\section{REFERENCES}

[1] Abd El-Kader, M.H., El-Sherbini, S.A., El-Tayeb, T.A., Mohamed, L.F. and Mohamed, S.A. (2001) Hematoporphyrin as photomolluscicide to control Fasciola snails. Proceedings of the 4th International Europe Mediterranean Conference on Laser, Photobiology, Applications in Medicine, Cairo University, Cairo, 13-16 February 2001, 46.

[2] Abd El-Meguid (1996) Effect of He-Ne laser beam on the Ommatidia in Schistsocerca gregaria. Arab Journal of Nuclear Sciences and Applications, 29, 53-67.

[3] Ben Amor, T., Tranchin, M., Bortolotto, L., Verdiglione, R. and Jori, G. (1998) Porphyrin and related compounds as photoactivable Insecticides. Photochemistry and Photobiology, 67, 206-211. doi:10.1562/0031-8655(1998)067<0206:PARCAP >2.3.C $\underline{\mathrm{O} ; 2}$

[4] Bertoloni, G., Sacchetto, R., Jori, G., Vernon, D.I. and Brown, S.B. (1993) Portophyrin photosensitization of Enterococcus hirae and Candida albicons cells. Lasers in the Life Sciences, 5, 267-275.

[5] El-Sayed, K.A. and El-Sherbini, S.A. (2006) Impact of Hematoporphyrin and different laser sources on Biomphalaria alexandrina snails and their infection with Schistosoma mansoni. Journal of Biological Chemistry, Environmental Sciense, 1, 319-340.

[6] El-Tarky, A.G.S. (2005) Semifield studies to control schistosomiaisis free larval stages and its snail vectors using selected sensitizers with sunlight and laser radiation. Ph.D. Thethis, National Institute of Laser Enhanced Sciences, Cairo University, Cairo.

[7] Jana, N.R., Earhart, C. and Ying, J.Y. (2007) Synthesis and covalent functionalization of nonoxidic iron core shellnanomagnetic. Chemistry of Materials, 19, 5074. doi:10.1021/cm071368z

[8] Lardans, V. and Dissous, C. (1998) Snail control strategies for reduction of schistosomiasis transmission. Parasitology Today, 14, 413-417. doi:10.1016/S0169-4758(98)01320-9

[9] Mohamed, S.H. and Saad, A.A. (1990) Histological studies on the Hermaphrodite gland of Limnaea caillaudi and Biomphalaria alexandrina upon infection with certain larval trematodes. Egyptian Journal of Histology, 13, 
47-53.

[10] Nolan, M.O., Howard, W.B. and Elizabeth, R.M. (1953) Results of laboratory screening tests of chemical compounds for molluscicidal activity. The American Journal of Tropical Medicine and Hygiene, 22, 716-752.

[11] Pasvol, G. and Hoffman, S. (2001) Trop. Med. Science and Practice "Schistosomiasis". Imperial College Press, 3, 12-17.

[12] Ragheb, M. (2009) Histological studies on the effect of gold nanoparticles on Scistosoma haematobium interme- diate host (Bulinus truncates snails). MSc. Thesis, Zoology Departement, Fuculty of Science, Cairo University, Cairo.

[13] Southwood, T.R.E. (1978) Ecological methods, with particular reference to the study of insect populations. The English Language Book Society and Chopan-Hall.

[14] Spikes, J.D. (1984) Photobiochemistry of porphyrins. In: Dorion D.R. and Comer, C.Z. Eds., Porphorin Localization and Treatment of Tumors, Alan R. Liss, New York, pp. 19-39. 